DOI: 10.46340/eujem.2020.6.6.8

Oleksandr Laiko, ScD in Economics

ORCID ID https://orcid.org/0000-0001-7082-0862

Institute of Market Problems and Economic-Ecological Research

of the National Academy of Sciences of Ukraine, Odesa

Anastasiia Bantash

ORCID ID https://orcid.org/0000-0002-6835-2104

Institute of Market Problems and Economic-Ecological Research

of the National Academy of Sciences of Ukraine, Odesa

Viktoriia Talpa

ORCID ID http://orcid.org/0000-0003-3003-9005

Institute of Market Problems and Economic-Ecological Research

of the National Academy of Sciences of Ukraine, Odesa

\title{
STATE OF THE INSTITUTIONAL ENVIRONMENT OF SOCIAL AND ECONOMIC DEVELOPMENT OF LOCAL COMMUNITIES IN UKRAINE
}

\author{
Олександр Лайко, д.е.н. \\ Анастасія Банташ \\ Вікторія Талпа \\ Інститут проблем ринку та економіко-екологічних досліджень НАН України, \\ м. Odeca
}

\section{СТАН ІНСТИТУЦІОНАЛЬНОГО СЕРЕДОВИЩА СОЦІАЛЬНО-ЕКОНОМІЧНОГО РОЗВИТКУ ТЕРИТОРІАЛЬНИХ ГРОМАД В УКРАЇНІ}

Local self-government reform is a long-awaited response to the public demand for the destruction of Ukraine's rigid neo-Soviet administrative and political system. The implementation of reforms related to the development of the foundations of self-government in Ukrainian society causes profound changes in the system of public administration, and it will involve communities in joint participation in policy development at the local and central levels. In this regard, the reform of local self-government will require a clear sequence and phasing in the implementation of institutional innovations in the social and economic spheres of life. The article considers the conceptual principles of development and improvement to the institutional framework of territorial communities' growth in the social and economic dimensions.

Key words: institutional environment, self-governance, institutional innovations, territorial community, decentralization.

Мета цієї статті - 3'ясувати стан інституційного середовища соціально-економічного життя територіальних громад України.

Виклад основного матеріалу. Соціально-економічний розвиток територіальних громад України виділений з усієї сукупності державних інтересів як актуальний і пріоритетний напрямок, оскільки кожна громада, будучи частиною єдиної держави, вносить свою частку в її історію, внутрішнє політичне, економічне, культурне життя, досягнення певних результатів на міжнародній арені. А організація господарської діяльності громад за допомогою взаємодії продуктивних сил своїх територій становить єдиний господарський комплекс країни.

Саме активізація соціального та економічного життя в громадах визначає тенденції зростання всієї країни. Світовий досвід свідчить про те, що держава є стійкою і життєздатною лише в тих 
випадках, коли іï суб’єкти (адміністративно-територіальні утворення) є політично стабільними, економічно і соціально життєдіяльними.

Таким чином, є очевидним, що дослідження проблем, пов'язаних з розробкою концепцій соціально-економічного розвитку громад, спрямованих на оптимізацію використання наявних в їх межах ресурсів і вибір основних пріоритетів у розвитку кожної з територіальних громад України, $\epsilon$ найбільш актуальним і в даний час ${ }^{1}$.

У сучасних умовах залучення суб' єктів господарювання до міжнародного економічного обміну та в контексті участі в інтеграційних процесах національного, регіонального рівня питання інституційної підтримки стає особливо гострим через появу нових викликів, формальних та неформальних нерівностей та створення відносин нового типу, наприклад, в рамках пов'язаних територіальних громад.

Також існує необхідність підтримувати ділову активність суб'єктів господарювання на базовому, регіональному рівнях шляхом активізації інвестиційної та інноваційної діяльності у стратегічно важливих видах економічної діяльності за допомогою стимуляторів прямих, непрямих способів дії та організаційних механізмів, які сприятимуть формуванню інституційного середовища, сприятливого для економічного розвитку громад².

Через інструменти децентралізації влади відбувається поділ повноважень між органами державної влади та органами місцевого самоврядування, посилення фінансових можливостей органів регіонального самоврядування і підвищення відповідальності органів місцевої влади перед громадами. Вже введені окремі елементи реформи адміністративно-територіального устрою, в т.ч. завдяки механізмам добровільного об'єднання територіальних громад, створено додаткові можливості для співпраці територіальних громад, введена реформа бюджетної децентралізації і тощо.

Ми виходимо 3 того, що трансформації в системі місцевого самоврядування співвідносяться 3 фундаментальними принципами становлення демократичного соціально-ринкової держави. Отже, завдання інституціоналізації самоврядування в Україні, що співвідноситься з європейськими самоврядними практиками на рівні громад, районів і областей, не може обмежуватися тільки децентралізацією влади.

Прогрес в посиленні спроможності місцевих громад сприятиме утвердженню основ прямої демократії і зростання ролі представницьких органів місцевого самоврядування. Підвищення відповідальності громад, розширення сфери їх впливу на управлінські рішення з питань розвитку будуть закономірно активізувати суспільний запит на продовження і поглиблення реформи самоврядування.

В результаті децентралізації посилиться самоврядування громад (інституційне, організаційне, фінансове), розширені повноваження органів місцевого самоврядування базового, районного та обласного (регіонального) рівнів вимагатимуть відповідного інституційного забезпечення на рівні центральної влади. ${ }^{3}$

Економічні та соціальні ініціативи з приводу регіонального розвитку повинні стати одним 3 найважливіших компонентів державної політики економічних реформ. Отже, органи самоврядування будуть здійснювати весь комплекс політик, які будуть стимулювати економічний розвиток територій: від підтримки існуючих видів бізнесу до стимулювання принципово нових видів економічної активності у виробництві і сфері послуг.

Стан інституціонального середовища визначає спроможність економічної системи країни, регіону або території до провадження ефективної господарської діяльності, можливість бути ефективним суб'єктом економічних відносин і забезпечувати сприятливе середовище для ведення бізнесу, що є особливо актуальним у сучасних умовах активної участі в інтеграційних процесах. Відсутність системного поєднання факторів розвитку бізнесу за різними складовими у вигляді інституціонального забезпечення $€$ визначальною проблемою, яку відзначають інвестори, що працюють в Україні.

\footnotetext{
${ }^{1}$ Studopedia (2020). Державне управління та місцеве самоврядування: проблеми взаємодії <http://studopedia.ru/11_70242_gosudarstvennoe-upravlenie-i-mestnoe-samoupravlenie-problemi-vzaimodeystviya.html> (2020, листопад, 17).

${ }^{2}$ Database (2020). Демографічний nасnорт території <http://database.ukrcensus.gov.ua/MULT/Dialog/ statfile1_c_files/pasport1.htm?73> (2020, листопад, 17).

${ }_{3}^{3}$ Moyaosvita (2020). Система місиевого самоврядування в Україні <http://moyaosvita.com.ua/pravovedenie/ sistema-mestnogo-samoupravleniya-v-ukraine/> (2020, листопад, 17).
} 
Внаслідок низької якості інституціонального забезпечення для провадження інвестиційної діяльності в Україні виникає проблема кількісної недостатності інвестицій, низької якості та структурної неефективності капіталовкладень.

У 2016-2017 рр. в Україні прийнято ряд важливих документів і постанов для децентралізації державного управління. Це Закон України «Про добровільне об' єднання територіальних громад» ${ }^{1}$, а також внесені зміни до Бюджетного та Податкового кодексів. В таких умовах зростає роль територіальних громад місцевого самоврядування в соціально-економічному розвитку країни завдяки ряду започаткованих реформ, з яких значна частина вже здійснюються.

Відповідно, з реалізацією реформи децентралізації значна частина повноважень i відповідальності у фінансовій та соціальній сфері переходить на місцеву владу, зокрема, в новостворені об'єднані територіальні громади, але виявляється безліч складних і болючих проблем в їх функціонуванні, від вирішення яких залежить в цілому соціально-економічний розвиток держави ${ }^{2}$.

На даний момент основною проблемою виступає належне виконання об'єднаними територіальними громадами своїх функцій, яка переплітається з питаннями наповнення бюджету, формуванням фінансових ресурсів, необхідних і достатніх для належного фінансування нагальних соціальних потреб громад на основі принципу субсидіарності, реалізації програми їх економічного, технологічного розвитку.

Станом на початок 2019 року в Україні створено 484 сільські об'єднані територіальні громади (ОТГ), або 40\% від 1293 запланованих урядом ${ }^{1}$. В даний час об’єднані 9240 сіл, що становить трохи менше 40\% від їх загальної кількості. Про проблему територіальної розпорошеності ОТГ свідчить етап об'єднання сіл навколо того чи іншого центру. Кількісні параметри об'єднання варіюються від 1 до 68 сіл, але в середньому до ОТГ з центром в місті або селищі міського типу приєднуються по 14 сіл, а з центром в селі - 9 .

Якщо плани уряду України не зміняться, то інші, майже 17 тис. сіл, будуть об'єднані ще в 809 ОТГ $\Gamma^{3}$.

Економічним підгрунтям функціонування будь-якої територіальної громади виступають ресурси, що знаходяться в їі володінні чи користуванні. Результатом добровільно створених об'єднань повинен стати належний рівень послуг з урахуванням кадрових ресурсів, фінансового забезпечення та розвитку інфраструктури відповідної адміністративно-територіальної одиниці ${ }^{4}$.

Потрібно констатувати, що, крім позитивних результатів, децентралізація має негативні наслідки. Зокрема, мова йде про розшарування суспільства за рівнем доходів, обезлюднення та соціально-економічному занепаді сільських територій, низький рівень розвитку підприємництва малого бізнесу на селі. Одна з причин такої ситуації полягає в несвоєчасному реагуванні на негативні прояви, що мали місце в процесах реформувань. У зв'язку з цим вкрай необхідно в ході реформ здійснювати глибокий аналіз і оцінку їх проміжних результатів. На сучасному етапі це актуально для реформи децентралізації в частині об'єднання громад в сільській місцевості.

Виваженість, обгрунтованість та ефективність адміністративно-територіальної реформи залежать від глибини і масштабності інституційної бази щодо соціально-економічних явищ i трансформаційних змін, що відбуваються внаслідок децентралізації.

Тому на сьогоднішній день принциповою $є$ оцінка об'єднаних територіальних громад на предмет їх інституційної спроможності до розвитку сільських територій усіх без винятку населених пунктів. Така грунтовна діагностика передбачає, перш за все, виявлення перспектив і ризиків розвитку сільських територій за даними аналізу проміжних результатів об'єднання територіальних громад в сільській місцевості. Це дозволяє обгрунтувати відповідні пропозиції щодо мінімізації ризиків для розвитку сіл, формуванню об'єднаних територіальних громад, які інституційно здатні до соціально-економічного розвитку сільських територій.

\footnotetext{
1 Закон України Про добровільне об'єднання територіальних громад, 2015 (Верховна Рада України).

Офіційний сайт Верховної Ради України <https://zakon.rada.gov.ua/laws/show/157-19\#Tехt> (2020, листопад, 17).

${ }^{2}$ Moyaosvita (2020). Система місиевого самоврядування в Украӥні

<http://moyaosvita.com.ua/pravovedenie/sistema-mestnogo-samoupravleniya-v-ukraine/> (2020, листопад, 17).

${ }^{3}$ Ligazakon (2009). Проект Закону Украӥни Про упорядкування сільської поселенської мережі

<http://search.ligazakon.ua/__doc2.nsf/link1/JF33W00B.html> (2009, лютий,05).

${ }^{4}$ Database (2020). Демографічний пасnорт території <http://database.ukrcensus.gov.ua/MULT/Dialog/

statfile1_c_files/pasport1.htm?73> (2020, November, 17).
} 
Аналізуючи інформацію, можемо говорити, що ця адміністративно-територіальна реформа неофіційно зводиться до цілей скорочення адміністративно-територіальних одиниць та укрупнення населених пунктів, що призводить до передачі місцевим органам влади всієї сфери соціальних послуг, наприклад, освіти та медицини ${ }^{1}$. Також варто відзначити, що зараз відбувається спроба скорочення кількості медичних і освітніх установ на місцях органами місцевого самоврядування. Саме тому на сьогодні у результаті, менше третини, навіть четвертої частини адміністративно-територіальних утворень об'єдналися в об'єднані територіальні громади (ОТГ $)^{2}$. Решта ж територій не виявляють бажання об'єднання, оскільки не бачать в цьому сенсу.

Так, як усвідомлюється те, що в результаті такого об'єднання в ОТГ, це може загрожувати їм закриттям вибраних шкіл або медичних установ. Тепер населенню необхідно буде добиратися до органів влади і до місць соціального обслуговування громадян набагато довше, ніж було раніше.

Варто також виділити недолік кваліфікації в процесі підготовки управлінців базового рівня, що заважає їм скористатися новими можливостями і перевагами адміністрування ресурсів. Для переходу на нові способи управління і розподілу ресурсів необхідні нові знання і навички, що $є$ відсутнім у багатьох, зокрема, селах. Різні соціально-економічні проблеми в ході реалізації реформи на місцях можуть призвести до ризику дискредитації реформи як такої на рівні окремих об'єднаних громад.

Недостатній рівень сформованості інституційної підтримки соціально-економічного розвитку територіальних громад України проявляється у надмірній бюджетній та управлінській централізації, нерозвиненості інститутів громадянського суспільства, відсутності чіткого розмежування земель державної та комунальної власності, дисбалансі просторового та регіонального розвитку, монофункціональність господарських комплексів у сільській місцевості, деградація людського капіталу та інертність сільського населення, неповна інвентаризація та кадастрова оцінка земель, нераціональне природокористування, незадовільна інституційна та психологічна база, зокрема, в сільській місцевості, низька спроможність діючих установ ${ }^{3}$.

Це знижує ефективність державної регіональної політики, перешкоджає процесам реалізації природно-ресурсного потенціалу, збільшенню обсягів сільськогосподарського виробництва, інвестиційної та інноваційної діяльності у територіальних громадах, збільшенню зайнятості сільських жителів та якості їх життя, адаптації України до інституційних вимог та стандарти ЄС з точки зору розвитку об'єднаних територій. Тому варто розробити заходи з покращення інституційного забезпечення соціально-економічного розвитку сільських територій.

Погано регульованим залишається питання базису законів соціально-економічного розвитку територіальних громад. Ряд розроблених нормативно-правових актів, поміж яких, для прикладу проект Закону України «Про планування територіальної інфраструктури ОТГ» та проект Закону України «Про упорядкування сільської поселенської мережі».

На рівні законодавства ${ }^{4}$ досі немає чіткого визначення поняття «об'єднана територіальна громада». Законодавча несформованість ускладнює реалізацію утилітарних засад політики держави в соціально-економічногму розвитку об'єднаних територіальних громад, на регіональному та державному рівнях створюються протиріччя управління, тому стримується розмежувальний процес комунальних та державних земель, цим перешкоджається визначення чітких меж територій, що підпадають під юрисдикцію територіальних громад, у зв'язку з цим знижується ефективність функціонування органів самоврядування на місцевому рівні, ускладнюється процес формування здатних територіальних громад та призводить до того, що переважаютьнеформальні інститути над формальними.

\footnotetext{
${ }^{1}$ Офіиійний сайт Верховної Ради України (2005). Проект Закону України Про планування територіальної інфраструктури сільської місиевості, 2005 (Верховна Рада України). Офіиійний сайт Верховної Ради України <http://w1.c1.rada.gov.ua/pls/zweb2/webproc4_1?pf3511=24247> (2005, квітень, 07).

${ }^{2}$ Moyaosvita (2020). Система місиевого самоврядування в Україні <http://moyaosvita.com.ua/pravovedenie/ sistema-mestnogo-samoupravleniya-v-ukraine/> (2020, листопад, 17).

3 Там само.

${ }^{4}$ Офіиійний сайт Верховної Ради Украӥни Проект Закону України Про планування територіальної інфраструктури сільської місиевості, 2005 (Верховна Рада України). <http://w1.c1.rada.gov.ua/pls/zweb2/ webproc4_1?pf3511=24247> (2005, квітень, 07); Ligazakon (2009). Проект Закону Украӥни Про упорядкування сільської поселенської мережі <http://search.ligazakon.ua/1_doc2.nsf/link1/JF33W00B.html> (2009, лютий,05).
} 
Функціонування законодавчих актів та докментів соціально-економічного розвитку територіальних громад обмежується їх характером декларативності.

В основному, в цих документах не встановлено засобів та інструментів досягнення пріоритетних цілей, відсутність чітких механізмів фінансування, здійснення запропонованих заходів, несформованість алгоритмів виконання положень програми. Недоцільним $є$ процес розроблення регіональних та державних програм розвитку об'єднаних територіальних громад насамперед в плані організації публічних слухань та обговорень, залученність досвіду науково-дослідних аграрних установ та неурядових організацій, врахування ідей представників органів місцевих рад та об'єднаних територіальних громад. А також відсутність дієвих механізмів тактико-оперативного коректування виконання програм соціально-економічного розвитку територіальних громад.

Розвиток територіальних громад визначається відсутністю належного дорожньо-транспортного 3'єднання, достатньої кількості об'єктів, фінансової, ринкової, інноваційної, підприємницької, побутової, комунікаційної, соціальної та культурної інфраструктури. Несформованість цих чинників перешкоджає розвитку підприємницької діяльності, створенню міжгосподарських об'єднань, налагодженню міжнародного співробітництва та поглиблює периферійний тип розвитку цих територій.

Населення об’єднаних територіальних громад, зокрема сільських, позбавлене можливості отримання якісних побутових, освітніх, соціальних, культурних та медичних послуг, які переважно надаються в містах, районних та обласних центрах. Також варто зазначити про, низьку функціональну здатність інфраструктури сільських територій, що входять в ОТГ ${ }^{1}$, що обмежує об'єми розвитку їх інституційного забезпечення, що проявляється у його дисбалансах, невідповідності та недосконалості сьогоднішнім вимогам і потребам, збільшенні частини трансакційних витрат у діяльності суб'єктів господарювання; непоширеності практики співпраці громадських і неурядових організацій з органами місцевого самоврядування.

Депресивність характеру розвитку ОТГ визначається монофункціональністю регіональної економіки та відсутністю робочих місць, що зумовлює міграційні процеси сільського населення до міста у пошуку роботи та деградація людського чиннику в сільській місцевості. Такі тенденції посилюють дію нестабільних впливів інституційних факторів на соціально-економічний розвиток об'єднаних територій, перш за все, в плані перешкоджання процесів формування інститутів українського села, освіти, громадянського суспільства, культури, місцевого лідерства та сім'ї'.

Ряд дослідників Сторонянська I., Максименко А., Левицька О., Патицька Х., Сірик 3. проводили опитування серед населення уже створенних ОТГ. До уваги брались головні проблеми, які впливали на розвиток соціально-економічного інституційного середовища. (Результати дослідження зображено у Таблииі 1$)^{3}$.

Деформація інституційних стимулів і безініціативність сільського населення підкріпляються в умовах їх низького рівня довіри до представників органів місцевого самоврядування та місцевих державних адміністрацій. Це утруднює i процеси утвердження особистостей, здатних до самоорганізаціїі та здійснення підприємницьких та громадських ініціатив, формуванняі зацікавленості серед жителів у вирішенні актуальних побутових господарських та культурних i проблем об'єднаних територій, на яких вони мешкають, нівелюютьі стимули до залучення фінансів трудових мігрантів у економіку сільської місцевості, посилюють соціально-економічні диспропорції культурного розвитку регіонів, спиняють становлення ефективного господарництваі на цихі територіях та їх структурнуі перебудову.

Також, серед негативних ознак виділяють відсутність чіткого розмежування між повноваженнямиі місцевих державних адміністрацій та органами місцевого самоврядування (відповідно до законодавства 76 повноважень $є$ дублюючими один одного $)^{4}$, що перешкоджає побудові ефективного механізму контролю за їх виконанням.

\footnotetext{
${ }^{1}$ Moyaosvita (2020). Система місиевого самоврядування в Україні <http://moyaosvita.com.ua/pravovedenie/ sistema-mestnogo-samoupravleniya-v-ukraine/> (2020, листопад, 17).

${ }^{2}$ Сторонянська, І., Максименко, А., Левицька та інші (2019). Соціально-економічне становище об'єднаних територіальних громад. Київ: НАН України.

3 Там само.

4 Там само.
} 


\section{Проблеми розвитку об'сднаних територіальних громад за рівнем напруження}

(1 - незначне, 5 - актуальне)

\begin{tabular}{|c|c|c|c|c|c|}
\hline & Проблеми & $\begin{array}{l}\text { Середня } \\
\text { оцінка }\end{array}$ & $\begin{array}{c}\text { Частка } \\
\text { населення, } \\
\text { хто вважає } \\
\text { що це } \\
\text { проблема }\end{array}$ & \% оцінки на 1 & \% оцінки на 5 \\
\hline 1 & Міграція населення в великі міста & 3,68 & $6 \%$ & $7 \%$ & $23 \%$ \\
\hline 2 & $\begin{array}{l}\text { Незначні можливості зайнятості } \\
\text { населення в межах ОТГ }\end{array}$ & 3,43 & $5 \%$ & $6 \%$ & $19 \%$ \\
\hline 3 & $\begin{array}{l}\text { Низька активність населення } \\
\text { у вирішенні питань діяльності ОТГ }\end{array}$ & 3,44 & $12 \%$ & $9 \%$ & $17 \%$ \\
\hline 4 & Дефіцит власних фінансових ресурсів & 3,77 & - & $19 \%$ & $20 \%$ \\
\hline 5 & $\begin{array}{l}\text { Відсутність людини яка б відстоювала } \\
\text { інтереси населення ОТГ }\end{array}$ & 3,07 & $22 \%$ & $19 \%$ & $19 \%$ \\
\hline 6 & Неофіційна зайняттість мешканців & 3,03 & $9 \%$ & $8 \%$ & $20 \%$ \\
\hline 7 & $\begin{array}{l}\text { Постійні зміни в документах щодо } \\
\text { діяльності ОТГ }\end{array}$ & 2,77 & $9 \%$ & $15 \%$ & $12 \%$ \\
\hline 8 & $\begin{array}{l}\text { Незлагоджена взаємодія з органами } \\
\text { влади інших щаблів }\end{array}$ & 2,66 & $24 \%$ & $20 \%$ & $9 \%$ \\
\hline 9 & $\begin{array}{l}\text { Невідповідний стан інфраструктури } \\
\text { або ж ії відсутність }\end{array}$ & 2,88 & $6 \%$ & $22 \%$ & $9 \%$ \\
\hline 10 & $\begin{array}{l}\text { В апараті ОТГ брак кваліфікованих } \\
\text { кадрів }\end{array}$ & 2,55 & $5 \%$ & $19 \%$ & $11 \%$ \\
\hline 11 & $\begin{array}{l}\text { Спротив місцевого населення дія } \\
\text { органів влади }\end{array}$ & 2,15 & $18 \%$ & $33 \%$ & $2 \%$ \\
\hline 12 & Відсутність співпраці з іншими ОТГ & 1,55 & $44 \%$ & $30 \%$ & $16 \%$ \\
\hline
\end{tabular}

*середня оиінка розраховувалась без уразування тих, хто вважає, щэо ие не проблема. Бралися до уваги очінки від 1 до 5.

Висновок. Реформа місцевого самоврядування знаходиться в стані фактичної незавершеності, незважаючи на проведення примусового етапу об'єднання, згідно перспективних планів, прийнятих обласними радами і затверджених Кабінетом міністрів України. Додатково до базового рівня незавершеним $\epsilon$ процес реформування системи державного управління на районному рівні, оскільки нові укрупнені райони утворені без чіткого визначення повноважень i функцій. Тому стан інституціонального забезпечення розвитку територіальних громад характеризується незеавершеністю. Недосконалістю та наявністю безлічі пасток, які знижують ступінь мотивації частини населених пунктів щодо активної участі в реформі та провадження заходів щодо розвитку економічних систем на базовому рівні, участі в проєктах співробітництва задля отримання додаткового фінансування від уряду або від структур СС на провадження заходів щодо покращенння рівня соціально-економічного розвитку. Інституціональна недосконалість незавершеність змушує наразі вітчизняну систему адміністративно-територіального устрою i самоврядування перебувати в стані невизначеності: з одного боку маємо частково реалізовану реформу, яка призвела до початку руйнування старої системи організації роботи органів місцевого самоврядування, а з іншого - наявна суттєва недосконалість нової системи державного управління на базовому і субрегіональному рівнях. 


\section{References:}

1. Studopedia (2015). Derzhavne upravlinnya ta mistseve samovryaduvannya: problemy vzayemodiyi [Public administration and local self-government: problems of interaction] <http://studopedia.ru/11_70242_ gosudarstvennoe-upravlenie-i-mestnoe-samoupravlenie-problemi-vzaimodeystviya.html> (2020, November, 17). [in Ukrainian].

2. State Statistics Service of Ukraine (2020). Demohrafichnyy pasport terytoriyi [Demographic passport of territory] <http://database.ukrcensus.gov.ua/MULT/Dialog/statfile1_c_files/pasport1.htm?73> (2020, November, 17). [in Ukrainian].

3. Moyaosvita (2016). Systema mistsevoho samovryaduvannya v Ukrayini [The system of local self-government in Ukraine] <http://moyaosvita.com.ua/pravovedenie/sistema-mestnogo-samoupravleniya-v-ukraine/> (2020, November, 17). [in Ukrainian].

4. Zakon pro dobrovilne obyednannya terytorialnykh hromad, 2015 (Verkhovna Rada Ukrayiny) [Law on Voluntary Amalgamation of Territorial Communities, 2015 (Verkhovna Rada of Ukraine)]. Ofitsiynyy sayt Verkhovnoyi Rady Ukrayiny [Official site of the Verkhovna Rada of Ukraine] <https://zakon.rada.gov.ua/laws/show/157-19\#Text> (2020, November, 17). [in Ukrainian].

5. Liha-Zakon (2009). Proekt Zakonu pro uporiadkuvannya silskoyi poselenskoyi merezhi [Draft Law on ordering of the rural settlement network] <http://search.ligazakon.ua/l_doc2.nsf/link1/JF33W00B.html> (2020, November, 17). [in Ukrainian].

6. State Statistics Service of Ukraine (2020). Demohrafichnyy pasport terytoriyi [Demographic passport of territory] <http://database.ukrcensus.gov.ua/MULT/Dialog/statfile1_c_files/pasport1.htm?73> (2020, November, 17). [in Ukrainian].

7. Ofitsiynyy sayt Verkhovnoyi Rady Ukrayiny (2005) [Official site of the Verkhovna Rada of Ukraine (2005)]. Proekt Zakonu pro planuvannya terytorialnoyi infrastruktury silskoyi mistsevosti [Draft Law on Rural Territorial Infrastructure Planning] <http://w1.c1.rada.gov.ua/pls/zweb2/webproc4_1 ?pf3511=24247> (2020, November, 17). [in Ukrainian].

8. Storonyanska, I., Maksymenko, A., Levitska, O. and others (2019). Sotsialno-ekonomichne i stanovyshche obyednanykh terytorialnykh hromad [Socio-economic and the position of the amalgamated territorialcommunities]. Kyiv: National Academy of Sciences of Ukraine. [in Ukrainian]. 